UDC 338.2

DOI: https://doi.org/10.32782/2520-2200/2021-2-2

\author{
Tsapko-Piddubna Olga \\ Ivan Franko National University of Lviv
}

\begin{abstract}
Цапко-Піддубна O.I.
кандидат економічних наук, доцент кафедри міжнародного економічного аналізу та фрінансів Львівського національного університету імені Івана Франка
\end{abstract}

\title{
EVALUATION OF INCLUSIVE GROWTH AND DEVELOPMENT POLICIES IN CENTRAL AND EASTERN EUROPEAN COUNTRIES
}

\section{ОЦІНЮВАННЯ ПОЛІТИКИ ІНКЛЮЗИВНОГО ЗРОТАННЯ ТА РОЗВИТКУ В КРАЇНАХ ЦЕНТРАЛЬНОÏ ТА СХІДНОÏ ЄВРОПИ}

The primary intension behind this study is to assess and compare policies that deliver inclusive outcomes to economic growth and development across economies of Central and Eastern Europe (CEE). The EU and Norway (the most inclusive country in 2018) were added into the study as a benchmark countries. As a result of the comparative analysis based on the World Economic Forum Inclusive Growth Policy and Institution Framework, we argue in favor of policies that would increase broad-based human economic opportunities and consequently both equality, and economic well-being of CEE economies. Positive strong influence on inclusive growth and development is associated with the employment and labor compensation policy that allows people directly increase their incomes; the basic services and infrastructure policy which is a necessary ground for present and future human and economic development; the asset building and entrepreneurship policy should provide diminishing inequality and rising economic opportunities by fostering medium and small business creation and enlarging possibilities of home and other asset ownership. In addition, an effective and inclusive redistribution state system of CEE economies should accentuate on supporting broad-based economic opportunities (like productive employment possibilities, asset building and entrepreneurship possibilities), along with infrastructure and human basic services development, rather than solely on social fiscal transfers.

Key words: inclusive growth and development, income and wealth inequality, economic opportunity.

У науковій літературі та у творенні політики розвитку інклюзивне економічне зростання вважають основою стійкого соціально-економічного розвитку країни, адже у зазначеній концепції економічного зростання увагу зміщено з темпів зростання ВВП на користь рівномірного розподілу багатства між населенням, зростання його економічних можливостей. Зважаючи на наукову актуальність теми та практичну необхідність переходу країн до стійкого соціально-економічного розвитку, у статті здійснено порівняльний аналіз політик, реалізація яких дозволить підвищувати інклюзивність економічного зростання у країнах Центральної та Східної Європи (ЦСЄ). 3 метою порівняння, наслідування та дорівняння, до аналізу додано Норвегію (найбільш інклюзивну економіку у 2018 р.) та ЄС. Серед досліджуваних країн ЦСЄ, Чехії та Словаччині найкраще вдалось змістити акценти з досягнення високих та стійких темпів економічного зростання на широко-розповсюджене підвищення добробуту населення та розширення його економічних можливостей. Загалом, варто відзначити, що економічний розвиток країн ЦСЄ - членів $Є С$ є більш інклюзивним. На противагу, для Російської Федерації, Молдови та України спостерігаємо негативні тенденції в цьому аспекті. На основі проведеного аналізу, виділено політики, які стимулюють інклюзивність соціально-економічного розвитку. Зокрема, це політики, реалізація яких забезпечує розвиток рівних економічних можливостей. Серед них: політика зайнятості (зростання продуктивної зайнятості, підвищення кваліфікації та перекваліфікації працівників, забезпечення врахування інтересів працівників як у оцінюванні їхньої оплати праці, так і у діяльності компаній), політика розвитку інфрраструктури та базових послуг (умова для гідного розвитку теперішнього та майбутніх поколінь, їхніх можливостей), політика сприяння генерування активів та розвитку підприємництва та ін. Варто окремо виокремити важливість політики з питань освіти та розвитку здібностей для забезпечення інклюзивної віддачі від зростання економіки. Згадана політика є основою для соціальної мобільності та конкурентоздатності економіки, за умови існування/стимулювання продуктивного виробництва та законодавчо врегульованого захисту інтересів працівників. В іншому випадку добре освічене та висококваліфіковане населення емігрує. Найменш розвинутою в Норвегії $€$ 
політика фріскальних трансфертів. Припускаємо, що для досягнення та підтримання інклюзивного зростання перерозподілу доходів не є достатньо. Проте, ця політика є не менш важливою, оскільки покликана створити соціальну систему захисту та водночас не стримувати економічне зростання.

Ключові слова: інклюзивне зростання та розвиток, нерівність доходів та багатства, економічні можливості, продуктивна зайнятість.

В научной литературе инклюзивный экономический рост считают основой устойчивого социально-экономического развития страны, ведь в указанной концепции экономического роста внимание смещено с темпов роста ВВП в пользу равномерного распределения богатства между населением, а также в пользу роста его экономических возможностей. Учитывая научную актуальность темы и практическую необходимость перехода стран к устойчивому социально-экономическому развитию, в статье проведен сравнительный анализ политик, реализация которых позволит повышать инклюзивность экономического роста в странах Центральной и Восточной Европы (ЦВЕ). С целью сравнения, подражания и уравнения, к анализу добавлено Норвегию (наиболее инклюзивную экономику в 2018) и ЕС. Среди исследуемых стран ЦВЕ, Чехии и Словакии лучше всех удалось сместить акценты с достижения высоких и устойчивых темпов экономического роста на широко-распространенное повышение благосостояния населения и расширение его экономических возможностей. Стоит отметить, что экономическое развитие стран ЦВЕ - членов ЕС является более инклюзивным. Напротив, для Российской Федерации, Молдовы и Украины наблюдаем негативные тенденции в этом аспекте. На основе проведенного анализа, выделены политики, стимулирующие инклюзивность социально-экономического развития. В частности, это политики, реализация которых обеспечивает развитие равных экономических возможностей. Среди них: политика занятости (рост продуктивной занятости, повышения квалификации и переквалификации работников, обеспечения учета интересов работников как в оценке их оплаты труда, так и в деятельности компаний), политика развития инфраструктуры и базовых услуг (условие для достойного развития нынешнего и будущих поколений, их возможностей), политика содействия генерирования активов и развития предпринимательства и др. Стоит отдельно выделить важность политики по вопросам образования и развития способностей для обеспечения инклюзивной отдачи от роста экономики. Упомянутая политика является основой для социальной мобильности и конкурентоспособности экономики, при условии существования/ стимулирования продуктивного производства и законодательно урегулированной защиты интересов работников. В противном случае хорошо образованное и высококвалифицированное население эмигрирует. Наименее развитая в Норвегии - политика фрискальных трансфертов. Предполагаем, что для достижения и поддержания инклюзивного роста перераспределения доходов не достаточно. Однако, эта политика является не менее важной, поскольку призвана создать социальную систему защиты и одновременно не сдерживать экономический рост.

Ключевые слова: инклюзивный рост и развитие, неравенство доходов и богатства, экономические возможности, продуктивная занятость.

Introduction. For a long time, economic growth has been a top policy goal around the world. Economists and policymakers have focused on a high-rated economic growth and accelerating cross-country convergence, while paying less attention to growing inequality of income, wealth, and opportunity. However, over the past several years, a worldwide consensus has emerged on the need for more socially inclusive approach to generate economic growth. For this reason, world organizations and scientists around the world have been working on the concept of inclusive growth and development. According to this concept, an economic growth should be distributed fairly across society and should create broad-based equal opportunities. As a result, nowadays this concept has become a central concern in the development literature and in policymaking in many countries. Economies which follow the pattern of inclusive growth and development (top-10 according to World Economic Forum report (WEF, 2018): Norway, Iceland, Luxemburg, Switzerland, Denmark, Sweden, Netherlands, Ireland, Australia, and Austria) prove to develop more sustainably and less susceptible to political, economic, and social instability.

The transition economies of Central and Eastern European countries (CEE countries-Czech Republic, Estonia, Hungary, Latvia, Lithuania, Moldova, Poland, Romania, Russian Federation, Slovak Republic, and Ukraine) with the abandonment of communist economic practices started the reformation process towards market economy intending for future sustained economic growth, equal opportunities, and prosperity for all their citizens. At the beginning of their transition process these countries were given advice to reform their economies according to neoliberalist set of rules-Washington Consensus. At that time, a scarce attention has been devoted to distributional patterns. The primary goal of economic policies was growth. But the transition reforms, like 
privatization, trade and financial liberalization/ deregulation not only led to development and growth, but also, they have contributed to the redistribution of income and wealth in societies breeding the stronger economic and political influence of more newly created affluent elites. Apart from this, similar transition policies bread different outcomes in terms of growth and inequality among CEE countries - countries that had similar pre-reformation economic development. The presumable reason for this is a difference in political and economic environment with certain rules and institutions which contribute to inclusion and equality.

Thus, the analysis based on the WEF Inclusive Growth Policy and Institution Framework would allow better insight of whether CEE countries have created the basic elements of such a system of structural policy incentives and institutions that widely diffuse the benefits of a developing economy in terms of income, opportunity, and quality of life as they have transited from centrally planned to market economy and at the same time integrated into the global economy.

Theoretical background. In the second half of XX century and in the early 2000 in the majority of national economies high-rated economic growth was at high priority. According to perseverant work of the neoclassical economists, that was the only way to earn countries' prosperity and as a result to improve the welfare of its citizens. They have believed and defended their point of view that with time economic growth would bring an increasing wealth and higher living standards to all sections of society. According to S. Kuznets (1955), economic growth would suffice to resolve the problems of inequality and poverty. His inverted U-hypothesis states that as per capita national income of a country increases, in the initial stage of growth, inequality in income distribution rises and after reaching the highest degree in the intermediate level the income inequality falls. Partially Kuznets's inverted U-hypothesis was true to industrialized countries in the post-war period - in the 1950s and 1960s every group was advancing, and those with lower incomes were rising most rapidly. Since than Kuznets's original hypothesis has been alternatively tested and as a result any strong evidence were found for the idea that differences in income would diminish pari passu with economic growth (D. Pini, 2015). The gains created by productivity increase, has far from been distributed evenly in societies.

Recently, economists' views have evolved to understanding that policies driven by an exclusive growth focus can set back inclusion and vice versa, high, and persistent inequality can undermine the sustainability of growth itself
(IMF, 2017). According to present approach, diminishing inequality is not a byproduct of growth process. Growth and inequality reduction can be instrumental to each other and they are a byproduct of a prudent policymaking.

J. Stiglits (2016) - Nobel laureate defends point of view that rules do matter as they determine how fast the economy grow, and who shares in the benefits of that prosperity. In addition, he argues that under the right rules, shared prosperity and strong economic performance reinforce each other. There is no trade-off, which means we do not have to sacrifice sustained economic growth for the sake of equality.

The research for transition economies presented by F. Novokmet, T. Piketty, L.Yang and G. Zucman (2018) suggests similar views: the rise in inequality is not inevitable; policies, institutions and ideology are important in shaping inequality.

With understanding that economic policies and institutions do matter as they define the redistribution of national income and are vital for creating opportunities, the inclusive growth and development concept have been taking ground around the world.

Research objective and methodology. International organizations and scholars have been working not only on the concept of inclusive growth and development. They also have made great contribution to practical aspects of its evaluation. For example, the WEF (2017) developed an alternative performance metric to GDP that evaluates inclusive socio-economic progress and enables to consider the distributional concerns. This performance metric of inclusive growth is represented by number of indicators that independently can evaluate progress in different spheres relevant to inclusive growth. At the same time values of these indicators are taken to calculate a composite index - the Inclusive Development Index (IDI), the score of which may vary from 1 to 7 (with 1 representing the worst case, and 7 - the best).

Moreover, the WEF developed framework (see Table 1) that highlights policies that deliver inclusive outcomes from growth. The framework represents the ecosystem of structural policy incentives and institutions that widely diffuse the benefits of an expanding national economy in terms of household income, opportunity, economic security, and quality of life. These policies are represented in pillars and their score may vary from 1 to 7 , with 1 representing the worst case, and 7 - the best one.

As Norway is the most inclusive economy in the world in 2017 and 2018 (WEF, 2017; 2018), its inclusive growth policies and institutions development pattern can serve as a benchmark. 
Table 1

Inclusive Growth Policy and Institution Framework. Source: World Economic Forum (2017)

\begin{tabular}{|c|c|c|c|}
\hline & Framework Pillars & $\begin{array}{r}\text { Types of indi } \\
\text { out }\end{array}$ & $\begin{array}{l}\text { ators for delivering inclusive } \\
\text { comes from growth }\end{array}$ \\
\hline 1. & $\begin{array}{l}\text { Education and } \\
\text { Skills Development }\end{array}$ & $\begin{array}{l}\text { a) Access } \\
\text { b) Quality } \\
\text { c) Equity }\end{array}$ & $\begin{array}{l}\text { to what extent is education at all levels } \\
\text { accessible, of high quality, and inclusive in } \\
\text { terms of attainment and learning outcomes? }\end{array}$ \\
\hline 2. & $\begin{array}{l}\text { Basic Services } \\
\text { and Infrastructure }\end{array}$ & $\begin{array}{l}\text { a) Basic and Digital } \\
\text { Infrastructure } \\
\text { b) Health-related Services } \\
\text { and Infrastructure }\end{array}$ & $\begin{array}{l}\text { to what extent are citizens provided with } \\
\text { adequate physical, digital infrastructure, and } \\
\text { high quality, affordable health service? }\end{array}$ \\
\hline 3. & $\begin{array}{l}\text { Corruption and } \\
\text { Rents }\end{array}$ & $\begin{array}{l}\text { a) Business and Political } \\
\text { Ethics } \\
\text { b) Concentration of Rents }\end{array}$ & $\begin{array}{l}\text { to what extent are broad-based economic } \\
\text { opportunity and efficient allocation of } \\
\text { resources through zero tolerance of bribery } \\
\text { and corruption, low barriers to entry, and fair } \\
\text { competition in product and capital markets } \\
\text { fostered? }\end{array}$ \\
\hline 4. & $\begin{array}{l}\text { Financial } \\
\text { Intermediation } \\
\text { of Real Economy } \\
\text { Investment }\end{array}$ & $\begin{array}{l}\text { a) Financial System Inclusion } \\
\text { b) Intermediation of Business } \\
\text { Investment }\end{array}$ & $\begin{array}{l}\text { to what extent does the financial system } \\
\text { deploy private savings for employment } \\
\text { generating productive purposes? }\end{array}$ \\
\hline 5. & $\begin{array}{l}\text { Asset Building and } \\
\text { Entrepreneurship }\end{array}$ & $\begin{array}{l}\text { a) Small Business Ownership } \\
\text { b) Home and Financial Asset } \\
\text { Ownership }\end{array}$ & $\begin{array}{l}\text { to what extent does the country foster } \\
\text { business creation and home ownership? }\end{array}$ \\
\hline 6. & $\begin{array}{l}\text { Employment } \\
\text { and Labor } \\
\text { Compensation }\end{array}$ & $\begin{array}{l}\text { a) Productive Employment } \\
\text { b) Wage and Non-wage } \\
\text { Labor Compensation }\end{array}$ & $\begin{array}{l}\text { to what extent is the country succeeding in } \\
\text { fostering widespread economic opportunity } \\
\text { in the form of robust job creation, broad } \\
\text { labor force participation and decent working } \\
\text { conditions? }\end{array}$ \\
\hline 7. & Fiscal Transfers & $\begin{array}{l}\text { a) Tax Code } \\
\text { b) Social Protection }\end{array}$ & $\begin{array}{l}\text { to what extent does a country's tax system } \\
\text { countervail income inequality without } \\
\text { undermining economic growth? } \\
\text { to what extent are a country's public social } \\
\text { protection systems engaged in mitigating } \\
\text { poverty, vulnerability, and marginalization? }\end{array}$ \\
\hline
\end{tabular}

Thus, it would be advisable for CEE economies to follow it. Besides, the EU average scores were added into research for comparison and as a benchmark for lowering the gap in the aspect of inclusiveness.

The in-depth analysis and comparison of Norway, the EU and analyzed CEE countries based on the WEF Inclusive Growth Policy and Institution Framework allows highlighting policies that would increase equality, economic wellbeing, and countries' competitiveness in the long run.

Results and discussion. The following part of this study is devoted to evaluation and comparison of CEE countries' inclusive growth and development policies implementation based on the WEF Inclusive Growth Policy and Institution Framework.

According to the WEF Key Performance Indicators and the WEF ranking (2018) most CEE economies are quite inclusive, and their IDI scores vary with a tendency of higher ones belonging to
EU members and lower - to non-EU countries (see Table 2).

The Czech and Slovak economies have the highest values of IDI. These countries succeeded in making their growth processes more socially inclusive during the transition to market economy. These two countries have higher scores in IDI ranking than based on GDP per capita among advanced economies (see Table 2). Similar pattern of growth is typical to Estonia, Romania, and Moldova. By contrast, Russian Federation and Ukraine have significantly lower rankings in IDI than in GDP per capita, suggesting that their economic growth has not transformed into social inclusion. Apart from this, Ukrainian IDI score is half lower of conceptually possible score and is the lowest among CEE economies.

As Norway and some CEE countries, like the Czech and Slovak Republic, Lithuania, and Estonia have succeeded in transforming their economic growth into social inclusion it is interesting to outline their best performing policies that provide 
Table 2

Comparative performance of IDI ranking versus GDP per capita ranking for Norway and CEE countries 2018. Source: World Economic Forum (2018)

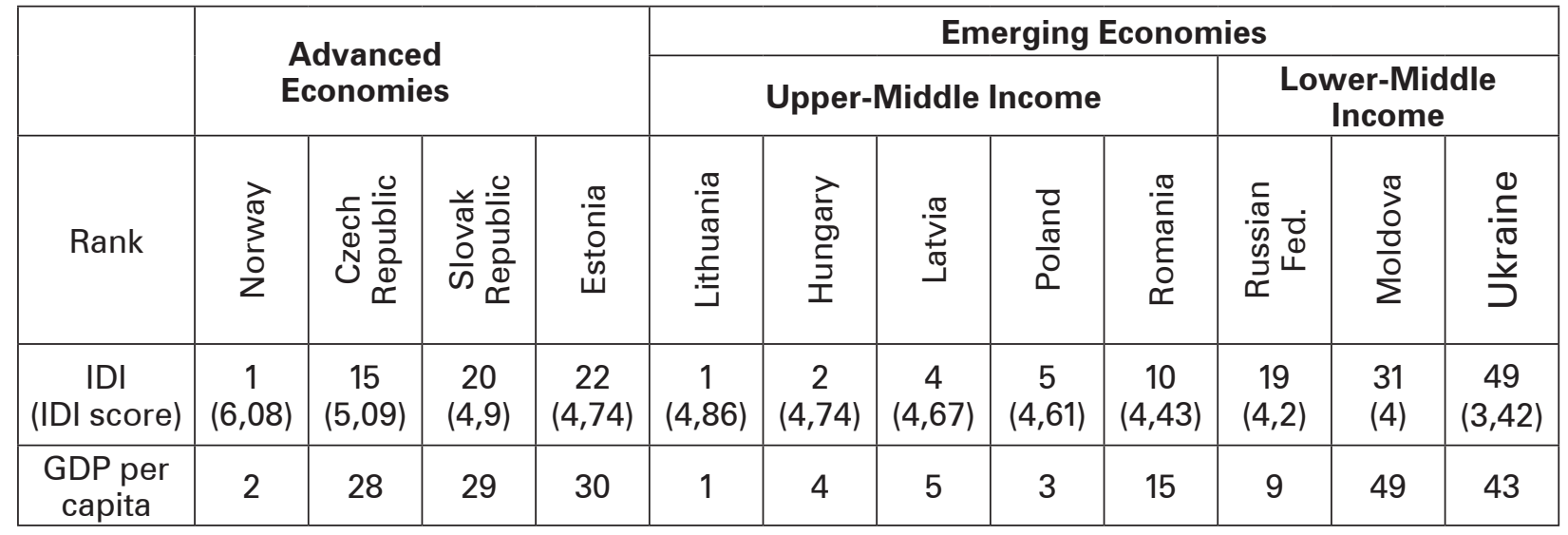

broad-based equal economic opportunities to all sections of society and are important in ensuring inclusive economic growth.

In Norway, the best performing is employment and labor compensation policy (see Tab. 3). This policy is a ground for fostering of widespread economic opportunity in the form of robust job creation, broad labor force participation and decent working conditions. It should provide an increase in productive employment and subsequently a direct increase in employees' incomes and in their self-awareness as of active and productive members of the society. Fair wages and well defended employees' interests (like in stakeholder capitalist model) are a key point to lowering income inequality.

For all CEE economies, this policy performance is below 5 (except Russia) and it is lower than EU average performance (except Estonia and Lithuania). A further development of this policy is advisable to promote inclusive growth and development.

The next well-developed inclusive growth policy in Norway is education and skills development policy. It is considered to foster widespread economic opportunity as it focuses on high quality, accessible and inclusive in terms of attainment and learning outcomes education. Its effective performance implies an increase in the skilled labor supply, a decrease in the relative skilled/unskilled wage and an overall decrease in income inequality. T. Piketty (2014) argues that the poor countries catch up with the rich when they achieve the same level of technological knowledge, qualification, and education. He suggests that education and skills development policy are very important for present and future decrease in income and wealth inequality.

Ukraine is a leader in this policy implementation The Ukrainian score of education and skills development pillar is the highest among CEE countries $(5,86)$, it is even higher than of the EU average score - 5,32 (see Tab. 3). Ukrainian education system can be described as supportive of inclusive growth, with high enrollment rates and equitable outcomes for students across socioeconomic levels. But whether it has positive influence on inclusiveness (as it is the least inclusive CEE economy) is in doubt. Perhaps people in Ukraine are well educated and intelligent but the level of education has little to do with their professional skills; or no matter how educated or skilled they are, they still fulfill the existing vacancies on labor market which are not highly productive or otherwise emigrate. Those countries, including Ukraine, that pay attention only to the supply of educated work force without creating productive workplaces, eventually prepare its people to emigration. Thus, well developed education and skill policy has no or little impact on inclusiveness of growth and development unless prudent complementary state policies are implemented. In particular policies on stimulating productive production and providing productive employment and fair labor compensation.

The other well-developed inclusive growth policy in Norway is basic services and infrastructure. An implementation of this policy is a necessary ground for present and future human and economic development. Such outcomes of its effective implementation as healthy nation and an adequate developed physical and digital infrastructure altogether attract investments into economies and increase economic activity there. Citizens of CEE countries are quite well provided with adequate physical, digital infrastructure, and high quality, affordable health service. The average CEE countries score for basic services and infrastructure is 5,10 and the EU average is 5,31. 
Table 3

Inclusive Growth Policy and Institution performance of Norway, CEE and the EU economies

\begin{tabular}{|c|c|c|c|c|c|c|c|}
\hline $\begin{array}{c}\text { Inclusive } \\
\text { Growth Policy } \\
\text { and Institution: }\end{array}$ & 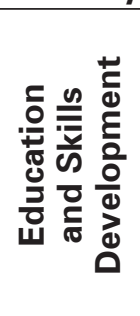 & 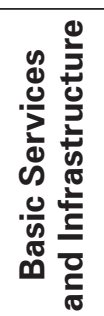 & 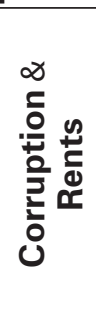 & 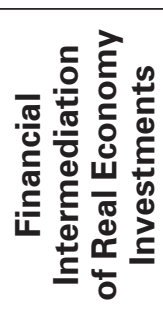 & 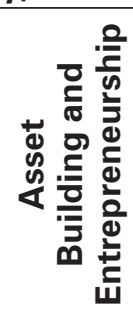 & 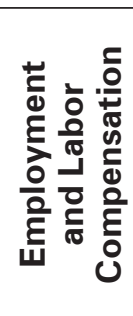 & 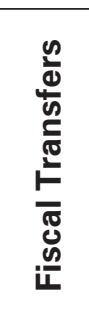 \\
\hline Norway & 5,99 & 5,72 & 5,39 & 5,41 & 5,19 & 6,12 & 4,52 \\
\hline EU & 5,32 & 5,31 & 4,36 & 4,07 & 4,58 & 4,65 & 4,12 \\
\hline CEE & 5,19 & 5,10 & 3,60 & 3,21 & 4,00 & 4,55 & 3,67 \\
\hline Slovak Republic & 4,79 & 4,91 & 3,37 & $\mathrm{~N} / \mathrm{A}$ & 3,93 & 4,26 & 3,31 \\
\hline Czech Republic & 5,29 & 5,24 & 3,76 & 3,62 & 4,21 & 4,50 & 3,72 \\
\hline Estonia & 5,72 & 5,30 & 4,51 & 3,78 & 4,82 & 4,78 & 3,39 \\
\hline Lithuania & 5,15 & 5,51 & 3,81 & 3,25 & 4,06 & 4,67 & 3,67 \\
\hline Hungary & 4,50 & 5,19 & 2,97 & 3,31 & 4,21 & 4,37 & 4,14 \\
\hline Poland & 5,41 & 5,21 & 4,08 & 3,65 & 4,02 & 4,22 & 3,69 \\
\hline Romania & 4,49 & 4,86 & 3,47 & 2,71 & 4,25 & 4,28 & 3,63 \\
\hline Latvia & 5,32 & 5,39 & 3,87 & 3,36 & 4,16 & 4,51 & 3,58 \\
\hline $\begin{array}{l}\text { Russian } \\
\text { Federation }\end{array}$ & 5,33 & 5,12 & 4,08 & 3,04 & 4,00 & 5,00 & 3,80 \\
\hline Moldova & 5,18 & 4,62 & 2,91 & 2,62 & 3,10 & 4,70 & 3,57 \\
\hline Ukraine & 5,86 & 4,75 & 2,81 & 2,71 & 3,29 & 4,78 & 3,84 \\
\hline
\end{tabular}

Source: authors' calculations based on World Economic Forum (2017) data

Policies of financial intimidation of real economy investment, and corruption \& rents are the next well-developed policies in Norway. As these policies matter for economies' inclusive growth and development the effectiveness of their implementation should be also fostered in CEE economies. At present the outcomes of these policies in CEE economies are slow and to some extent ineffective reforms (depending on the country) in fighting bribery and corruption; lowering barriers to entry and fostering fair competition in product and capital markets; enhancing private savings for employment generating productive purposes.

In Norway, the asset building and entrepreneurship policy is also at priority as it favors more socio-inclusive growth by fostering medium and small business creation, enlarging possibilities of home and other asset ownership. As a result, an effective asset building and entrepreneurship policy should decrease income and wealth inequality and subsequently widen economic opportunities. As it concerns CEE economies, their average score for this policy is 4 (comparing with EU average - 4,58, Norway - 5,19) which implies that still much has to be done.

The least developed policy in Norway is fiscal transfers. Perhaps redistribution of national income is not that important as above policies which directly favor human broad-based eco- nomic opportunities like employment \& labor compensation; education \& skills development; basic services \& infrastructure; and asset building $\&$ entrepreneurship policies.

Among CEE economies the most effective fiscal system in the sense of inclusiveness is in Hungary. For all the rest CEE countries there is much to be done for further improvements. The CEE countries' average score of fiscal transfers' policy pillar $(3,67)$ is lower than of the EU one $(4,62)$. CEE countries' governments should better use taxes and transfers to moderate differences in income and wealth. And at the same time well-designed, prudent fiscal transfers policy should not hamper economic growth. Its primary goal should be creation of such a public social protection system that is engaged in decreasing poverty, vulnerability, and marginalization. It is suggested to use better well-known fiscal instruments, for example, by making tax system more progressive, scaling back tax deductions, eliminating tax exemptions and by ensuring greater tax compliance.

Conclusions. The CEE countries' further development should go in line with inclusive growth and development theory in order to generate inclusive socio-economic progress and broad-based improvements in living standards. Prudent policymaking that simultaneously support economic growth and inequality reduction, as long 
as promotion of equal economic opportunities will enable broad-based prosperity.

EU membership obviously supports such the inclusive growth policymaking as EU members CEE economies perform better in IDI scores than non-EU countries. The Czech and Slovak Republic are the best performing economies among CEE countries in inclusive growth and development patterns. On the contrary Ukraine, Moldova, and Russian Federation - the worst. These countries economic growth has not transformed well into social inclusion.

As for the inclusive growth and development policies assessment, there are no great disparities across CEE countries. These countries follow similar patterns of policy development and implementation. There are greater disparities across policies in each country. The best performing policies that deliver inclusive outcomes from economic growth by providing broad-based equal economic opportunities to all sections of societies are: the employment and labor compensation policy that allows people directly increase their incomes and feel themselves as active and productive members of the society; the basic services and infrastructure policy that is a necessary ground for present and future human and economic development; the asset building and entrepreneurship policy that provides diminishing inequality and rising economic opportunities by fostering medium and small business creation and enlarging possibilities of home and other asset ownership; and education and skills development policy that is necessary for social mobility and for transition countries catching up processes. Although, Ukraine has the highest score in the later policy performance, its influence on inclusiveness is scarce. Perhaps, well-developed education and skill policy has no or little impact on inclusiveness of growth and development unless prudent state policy on stimulating productive production is implemented and an effective employment and labor compensation policy is pursued. Otherwise, well-educated, and qualified labor force is forced to emigrate.

The least performing policies in CEE countries are corruption and rents; financial intermediation of real economy investments; and fiscal transfers policies. As for the later policy, redistribution of national income is not determinant to inclusive growth and development, but nevertheless it should create a public social protection system that is engaged in decreasing poverty, vulnerability, and marginalization without hampering economic growth. It is advisable for CEE countries to make tax system more progressive, scale back tax deductions, eliminate tax exemptions and ensure greater tax compliance. An effective and inclusive redistribution state system of CEE economies should accentuate on supporting economic opportunities rather than on social fiscal transfers.

\section{References:}

1. Kuznets S. (1955) Economic Growth and Income Inequality. American Economic Review, no. 1(45) pp. 1-28.

2. Pini D. (2015) The Kuznets Curve and Inequality: A Comparative Study of 27 OECD Countries Across 30 years of Neo-Liberal Economic Policies. Johns Hopkins University Press, pp. 1-38. Available at: https://econ.jhu.edu/wpcontent/uploads/sites/27/2016/02/Pini-The-Kuznets-Curve-and-Inequality.pdf.

3. International Monetary Fund (2017). Fostering Inclusive Growth. G-20 Leaders' Summit, July 7-8, 2017. IMF working paper, pp. 1-36. Available at: https://www.imf.org/external/np/g20/pdf/2017/062617.pdf.

4. Stiglitz J.E. (2016) Rewriting the Rules of the American Economy: An Agenda for Growth and Shared Prosperity. Roosevelt Institute, pp. 1-115. Available at: https://community-wealth.org/sites/clone. community-wealth.org/files/downloads/report-stiglitz.pdf.

5. Novokmet F., Piketty T., Yang L., Zucman G. (2018) From Communism to Capitalism: Private Versus Public Property and Inequality in China and Russia. World Inequality Database, № 2018/2. Available at: https://wid.world/document/communism-capitalism-private-versus-public-property-inequality-china-russia-wid-world-working -paper-2018-2.

6. World Economic Forum (2017). The Inclusive Growth and Development Report 2017. WEF working paper, pp. 1-75. Available at: http://www3.weforum.org/docs/WEF_Forum_IncGrwth_2017.pdf.

7. World Economic Forum (2018). The Inclusive Development Index 2018 Sümmary añ Data Highlights. WEF working paper, pp. 1-14. Available at: http://www3.weforum.org/docs/WEF_Forum _IncGrwth_2018.pdf.

8. Piketty T. (2014) Capital in the Twenty-First Century. Harvard University Press, 1-452. 